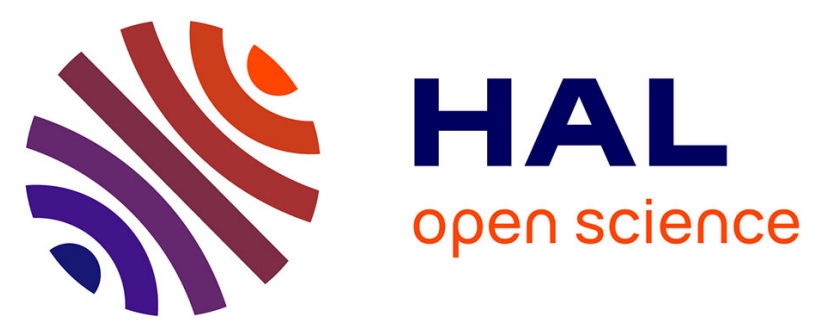

\title{
Exposure of larvae to thiamethoxam affects the survival and physiology of the honey bee at post-embryonic stages
}

\author{
Daiana Antonia Tavares, Claudia Dussaubat, Andre Kretzschmar, Stephan \\ Malfitano Carvalho, Elaine C.M. Silva-Zacarin, Osmar Malaspina, Géraldine
} Bérail, Jean-Luc Brunet, Luc Belzunces

\section{To cite this version:}

Daiana Antonia Tavares, Claudia Dussaubat, Andre Kretzschmar, Stephan Malfitano Carvalho, Elaine C.M. Silva-Zacarin, et al.. Exposure of larvae to thiamethoxam affects the survival and physiology of the honey bee at post-embryonic stages. Environmental Pollution, 2017, 229, pp.386-393. 10.1016/j.envpol.2017.05.092 . hal-01559707

\section{HAL Id: hal-01559707 https://hal.science/hal-01559707}

Submitted on 10 Jul 2017

HAL is a multi-disciplinary open access archive for the deposit and dissemination of scientific research documents, whether they are published or not. The documents may come from teaching and research institutions in France or abroad, or from public or private research centers.
L'archive ouverte pluridisciplinaire HAL, est destinée au dépôt et à la diffusion de documents scientifiques de niveau recherche, publiés ou non, émanant des établissements d'enseignement et de recherche français ou étrangers, des laboratoires publics ou privés.

\section{다(1)(2)}

Distributed under a Creative Commons Attribution - ShareAlikel 4.0 International 


\title{
Exposure of larvae to thiamethoxam affects the survival and physiology of the honey bee at post-embryonic stages ${ }^{\text {th }}$
}

\author{
Daiana Antonia Tavares a, *, Claudia Dussaubat ${ }^{\mathrm{b}}$, André Kretzschmar ${ }^{\mathrm{c}}$, \\ Stephan Malfitano Carvalho ${ }^{\mathrm{d}}$, Elaine C.M. Silva-Zacarin ${ }^{\mathrm{e}}$, Osmar Malaspina ${ }^{\mathrm{a}}$, \\ Géraldine Bérail ${ }^{\mathrm{f}}$, Jean-Luc Brunet ${ }^{\mathrm{b}}$, Luc P. Belzunces ${ }^{\mathrm{b}}{ }^{* * *}$ \\ a UNESP, Universidade Estadual Paulista, Departamento de Biologia, Rio Claro, São Paulo, Brazil \\ ${ }^{\mathrm{b}}$ INRA, Laboratoire de Toxicologie Environnementale, UR 406 Abeilles \& Environnement, Avignon, France \\ ${ }^{\mathrm{c}}$ INRA, UR 546 Biostatistique et Processus Spatiaux, Avignon, France \\ d UFLA, Universidade Federal de Lavras, Lavras, Minas Gerais, Brazil \\ e UFSCar, Universidade Federal de São Carlos, Sorocaba, São Paulo, Brazil \\ I INRA, Laboratoire de L'Environnement et de L'Alimentation de La Vendée, La Roche sur Yon, France
}

Keywords:

Apis mellifera

Neonicotinoids

Larvae

Pupae

Toxicity

Development

\begin{abstract}
A B S T R A C T
Under laboratory conditions, the effects of thiamethoxam were investigated in larvae, pupae and emerging honey bees after exposure at larval stages with different concentrations in the food $(0.00001 \mathrm{ng} / \mu \mathrm{L}, 0.001 \mathrm{ng} / \mu \mathrm{L}$ and $1.44 \mathrm{ng} / \mu \mathrm{L})$. Thiamethoxam reduced the survival of larvae and pupae and consequently decreased the percentage of emerging honey bees. Thiamethoxam induced important physiological disturbances. It increased acetylcholinesterase (AChE) activity at all developmental stages and increased glutathione-S-transferase (GST) and carboxylesterase para (CaEp) activities at the pupal stages. For midgut alkaline phosphatase (ALP), no activity was detected in pupae stages, and no effect was observed in larvae and emerging bees. We assume that the effects of thiamethoxam on the survival, emergence and physiology of honey bees may affect the development of the colony. These results showed that attention should be paid to the exposure to pesticides during the developmental stages of the honey bee. This study represents the first investigation of the effects of thiamethoxam on the development of $A$. mellifera following larval exposure.
\end{abstract}

\section{Introduction}

The honey bee Apis mellifera plays an important role at the economic and environmental levels. It contributes to more than $80 \%$ of the total pollination in agriculture and plays an important role in the pollination in ecosystems (Klein et al., 2007; Breeze et al., 2011). Gallai et al. (2009) estimated that the economic value of pollination in global scales is approximately $€ 153$ billion per year. However, there is an increasing number of reports on the decline of the bee population worldwide. This decline is characterized by the

4 This paper has been recommended for acceptance by Dr. Chen Da.

* Corresponding author. UNESP, Universidade Estadual Paulista, Departamento de Biologia, Avenida 24A, nº1515, 13506-900, Rio Claro, São Paulo, Brazil.

** Corresponding author. INRA, Laboratoire de Toxicologie Environnementale, UR 406 A\&E, CS 40509, Avignon Cedex 9, France.

E-mail addresses: daianazoo@yahoo.com.br (D.A. Tavares), luc.belzunces@inra.fr (L.P. Belzunces) mass disappearance of bees in the United States (including colony collapse disorder (CCD)) and, in numerous cases, by losses of managed and wild pollinators in Europe and Asia (Stokstad, 2007; Potts et al., 2010). This raises the discussion among beekeepers, researchers, the chemical industry and governmental agencies about the factors involved in this syndrome. Several causes have been identified to explain the decline in the bee population, highlighting beekeeping management, agricultural practices, loss of floral diversity, habitat fragmentation and rarefication, pathogens, parasites and pesticides (Ratnieks and Carreck, 2010; Goulson et al., 2015).

An epidemiological study was performed in 2013 to explain the loss of honey bee colonies in Europe (Chauzat et al., 2013). If we exclude the problems of diseases (e.g., varroosis or nosemosis), the intoxication with pesticides could also, at least partially, explain the colony losses. Among pesticides, neonicotinoid insecticides represent the main family of insecticides used worldwide (Blacquiere 
et al., 2012; Sparks and Nauen, 2014). They act as agonists of the nicotinic acetylcholine receptors of insects (nAChR) (Tomizawa and Casida, 2003). They are characterized by the systemic properties and xylem and phloem transports enable them to be distributed in all plant tissues and to contaminate pollen and nectar, the two main food resources of bees (Rortais et al., 2005). They thus have adverse effects on bees, such as behaviour impairment or morphological and physiological disturbances (Henry et al., 2012; Goulson et al., 2015). Therefore, the effects and the properties of neonicotinoids suggest that they pose the greatest risk to honey bees (SanchezBayo and Goka, 2014).

Within this class of insecticides, thiamethoxam, a secondgeneration neonicotinoid, can be regarded as an active substance of high concern (Maienfisch et al., 2001). Honey bees can be exposed to thiamethoxam and other neonicotinoids because they usually explore areas in a radius up to $12 \mathrm{~km}$ around the hive to collect floral resources, water and resins, increasing the risk of exposure at lethal and sublethal levels (Beekman and Ratnieks, 2000).

In addition to honey bee foragers, larvae could also be exposed to neonicotinoids from residues contained in pollen, nectar, water and wax stored in the hive (Rortais et al., 2005; Desneux et al., 2007; Couvillon et al., 2014; Sanchez-Bayo and Goka, 2014; Johnson, 2015). Thiamethoxam has been found at concentrations ranging from 1 to $100 \mu \mathrm{g} / \mathrm{kg}$ in nectar, pollen and plant secretions (and some other environmental matrices) (Blacquiere et al., 2012; Bonmatin et al., 2014; Kessler et al., 2015) and at a concentration of $0.6 \mu \mathrm{g} / \mathrm{kg}$ in beebread (Giroud et al., 2013).

The post-embryonic period of honey bees may be considered crucial because the exposure to xenobiotics can cause irreversible damage at the cellular, physiological and morphological levels, which can jeopardize the development of the honey bee (Becher et al., 2013; Tavares et al., 2015). At present, the side effects induced by an exposure to neonicotinoids during the postembryonic period are poorly investigated (Desneux et al., 2007; Blacquiere et al., 2012), although some studies have demonstrated toxicity to bumblebees, which includes an increased mortality, a reduced efficiency of pollen collection and a reduced growth rate (Mommaerts et al., 2010; Whitehorn et al., 2012; Gill et al., 2012; Elston et al., 2013; Laycock et al., 2014).

To study honey bee health, the approach involving the use of biomarkers appears to be particularly pertinent to assess the physiological responses of honey bees after exposure to xenobiotics and to understand the mechanisms involved in the toxicity and the adaptation to environmental changes (Jovanovic-Galovic et al., 2004; Badiou-Beneteau et al., 2012; Boily et al., 2013; Carvalho et al., 2013; Badawy et al., 2015). Some biomarkers are particularly used to assess the physiological effects of environmental stressors. Acetylcholinesterase (AChE, EC 3.1.1.7) is an enzyme that controls the neuronal activity of cholinergic synapses (Badiou et al., 2008). Carboxylesterases (CaE, EC 3.1.1.1) and glutathione-S-transferase (GST 2.5.1.1.8) are phase I and phase II enzymes involved in the detoxification and endocrine systems (Yu et al., 1984; Maxwell, 1992; Diao et al., 2006). Alkaline phosphatase (ALP, EC 3.1.3.1) hydrolyses the phosphate group of different substrates and is involved in the absorption of substances, in intestinal integrity and homeostasis, and in the immunity process (Moss, 1992; Millán, 2006; Lallès, 2010).

In this study, we have investigated the effects of thiamethoxam in larvae, pupae and emerging workers following exposure at the larval stage. The study was focused on the success of postembryonic development and on the physiological disturbances assessed by the modulation of the biomarkers AChE, GST, CaEp and ALP.

\section{Materials and methods}

\subsection{Chemicals}

Thiamethoxam (98.5\% pure) was purchased from Dr. Ehrenstorfer $\mathrm{GmbH}$. Yeast extract, D-glucose, D-fructose, antipain, aprotinin, leupeptin, pepstatin A, soybean trypsin inhibitor, monosodium phosphate, sodium chloride $(\mathrm{NaCl})$, Triton ${ }^{\circledR} \mathrm{X}-100$, acetylthiocholine iodide (AcSCh.I), 5,5'dithio-bis(2,nitrobenzoic acid) (DTNB), reduced L-glutathione (GSH), ethylenediaminetetraacetic acid (EDTA), 1-chloro-2,4-dinitrobenzene (CDNB), Trizma ${ }^{\circledR}$ base (Tris), hydrochloric acid ( $\mathrm{HCl})$, magnesium chloride $\left(\mathrm{MgCl}_{2}\right), p$ nitrophenyl phosphate ( $p$-NPP), $1,5-\operatorname{bis}(4-$ allyldimethylammonium-phenyl)pentan-3-one-dibromide

(BW284C51) and $p$-nitrophenyl acetate ( $p$-NPA) were obtained from Sigma Aldrich (France). Royal jelly was purchased from Ickowicz Apiculture (Bollène, France).

\subsection{Collection of honey bee larvae and maintenance during development}

Four colonies of Apis mellifera honey bees, previously checked for their health status, were selected from the experimental apiary of the Abeilles \& Environment Research Unit (INRA, Avignon, France). Each colony had 6 to 7 brood frames and was supervised during the experiments to ensure good condition of the individuals. Larvae rearing was performed according to the method developed by Aupinel et al. $(2005,2007)$ and adopted by OECD (2013). To obtain larvae of a known age, three days before the experiment, combs containing empty cells were previously equipped with a queen excluder and placed in the hive for egg laying. The fourth day, 1 st instar larvae were transferred into plastic queen-startercells and placed in an incubator under controlled conditions $\left(34 \pm 2{ }^{\circ} \mathrm{C}\right.$ and $95 \pm 5 \%$ relative humidity $(\mathrm{RH})$ ). At the 7 th day, the $\mathrm{RH}$ was changed to $80 \%$ for the pupation period. On the 15 th day (emergence period), each plate was individually sealed with a thin layer of beeswax so that each cell was individualized. In each cell, orifices were made on the top to enable air exchange. The plates were individually accommodated in pots upright, simulating colony conditions. Temperature and $\mathrm{RH}$ were identical to those of the pupation period. To feed the emerging honey bees, candy and distilled water were provided ad libitum.

\subsection{Larvae feeding}

Larvae were provided with food at the daily intakes recommended for each developmental stage (OECD, 2013). Food was composed of 1 volume of royal jelly and 1 volume of an aqueous solution containing $12 \%(\mathrm{w} / \mathrm{v})$ glucose, $12 \%$ fructose and $2 \%$ yeast extract (diet A); $15 \%$ glucose, $15 \%$ fructose and 3\% yeast extract (diet B); or $18 \%$ glucose, $18 \%$ fructose and $4 \%$ yeast extract, plus or minus (control) thiamethoxam (diet C). The daily feeding of larvae (volume per diet and per day) was performed from the 1st day (grafting) to the 6th day, except for the 2nd day, which was considered a period of acclimatization. The diet was: $20 \mu \mathrm{L}$ of $\operatorname{diet} \mathrm{A}$ on the 1 st day, $20 \mu \mathrm{L}$ of diet B on the 3rd day, and 30,40, and $50 \mu \mathrm{L}$ of diet $C$ on the 4 th, 5 th and 6 th days, respectively.

\subsection{Exposure to thiamethoxam}

To expose larvae, three concentrations of thiamethoxam were selected: $0.00001,0.001$ and $1.44 \mathrm{ng} / \mu \mathrm{L}$ of the diet. The two lowest concentrations were close to the levels of residues found in nectar, pollen and beebread (Rortais et al., 2005; Desneux et al., 2007; Mullin et al., 2010; Blacquiere et al., 2012; Krupke et al., 2012; 
Stoner and Eitzer, 2012; Giroud et al., 2013; Pilling et al., 2013; Bonmatin et al., 2014; Couvillon et al., 2014; Sanchez-Bayo and Goka, 2014; Johnson, 2015; Kessler et al., 2015). The highest concentration was selected according to a previous study (Tavares et al., 2015) and was equivalent to $1 / 10$ of the $\mathrm{LC}_{50}$ in Africanized Apis mellifera larvae. Thiamethoxam was added directly to the larval food (diet C) from a stock solution prepared in distilled water after purity correction. The control group received only the uncontaminated diet. Acute exposure was performed on the 4th day after grafting (PG) by providing $30 \mu \mathrm{L}$ of diet $\mathrm{C}$ containing thiamethoxam at the appropriate concentrations. The concentrations of the stock solutions of thiamethoxam were checked according to Wiest et al. (2011), and the relative standard deviations (RS) were less than $10 \%$. At the thiamethoxam concentrations used, the doses per larvae were $0.0003,0.03$ and $43.2 \mathrm{ng} /$ larvae. Larval mortality was checked individually by observation under a stereomicroscope at the 5th, 6th and 8th days PG. Pupal mortality was checked at the 11 th, 13 th and 15 th days PG, and the percentage of adult emergence enabled the estimation of the success of the pupae phase, which occurred between the 15th and the 20th day PG. Bees were considered emerging when individuals left the artificial cells. The experiments were conducted from May to June 2014. For the bioassays, experimental replicates of 48 larvae from at least 3 colonies were adopted. For each bioassay, an experimental duplicate or triplicate was made $n=96$ larvae per group or $n=144$ larvae per group, and data were analysed.

\subsection{Analysis of the physiological markers}

The samples collected at the different developmental stages were 5 th instar larvae, black-eye pupae with the cuticle slightly tanned (Pdl) and newly emerged workers (emerging bees) (Rembold et al., 1980; Michelette and Soares, 1993; Cruz-Landim, 2009). Different tissues were used for enzymatic analysis. AChE and GST were extracted from the whole body of larvae and the head of pupae and emerging bees. CaEp and ALP were extracted from the whole body of larvae, the abdomens of pupae and the midgut of emerging bees. For each enzyme and at each exposure condition and developmental stage, 7 extracts each containing 3 body parts were assayed in triplicate. Bee tissues were homogenized with Tissuelyser $\left(\right.$ Qiagen $^{\circledR}$ ) to make a $10 \%(\mathrm{w} / \mathrm{v})$ tissue extract, for $5 \times 10 \mathrm{~s}$ at $30 \mathrm{~Hz}$, in the extraction medium composed of $10 \mathrm{mM}$

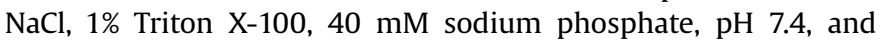
containing $2 \mathrm{mg} / \mathrm{ml}$ antipain, $2 \mathrm{mg} / \mathrm{ml}$ leupeptin, $2 \mathrm{mg} / \mathrm{ml}$ pepstatin A, 25 units/ml aprotinin and $0.1 \mathrm{mg} / \mathrm{ml}$ soybean trypsin inhibitor. After homogenization, samples were centrifuged for $20 \mathrm{~min}$ at $15,000 \mathrm{~g}$, and the supernatants were recovered for analysis. All procedures were performed at $4{ }^{\circ} \mathrm{C}$. Enzyme kinetics were followed with a multimode microplate reader Infinite F500 ( Tecan $^{\circledR}$ ) at $25^{\circ} \mathrm{C}$ in a final reaction volume of $200 \mu \mathrm{L}$. AChE activity was measured at $412 \mathrm{~nm}$ in a medium containing $0.3 \mathrm{mM}$ AcSCh.I, $1.5 \mathrm{mM}$ DTNB and $100 \mathrm{mM}$ sodium phosphate $\mathrm{pH}$ 7.0. GST activity was measured at $340 \mathrm{~nm}$ in a medium containing $2.5 \mathrm{mM} \mathrm{GSH}, 1 \mathrm{mM}$ EDTA, $1 \mathrm{mM}$ CDNB and $100 \mathrm{mM} \mathrm{Na/K}$ phosphate, $\mathrm{pH}$ 7.4. CaEp activity was measured at $410 \mathrm{~nm}$ in a reaction medium containing $0.01 \mathrm{mM}$ BW284C51, an AChE inhibitor, $0.1 \mathrm{mM}$ of $p$-NPA and $100 \mathrm{mM}$ sodium phosphate, $\mathrm{pH} 7.5$. ALP activity was measured at $410 \mathrm{~nm}$ in a medium containing $20 \mathrm{mM} \mathrm{MgCl}_{2}, 2 \mathrm{mM} p$-NPP and $100 \mathrm{mM}$ Tris$\mathrm{HCl}, \mathrm{pH} 8.5$.

\subsection{Statistical analyses}

All data were analysed using the statistical R Development Core Team (2015). Survival data were analysed using the Cox proportional hazards regression model (survival package), and significant differences were denoted when $P<0.05$. The influence of thiamethoxam on emergence success was analysed by a chi-square test that makes pairwise comparisons between exposed and control groups, with $1 \mathrm{df}$ and $P<0.001$. Enzymatic data were analysed by the pairwise Wilcoxon rank sum tests from the package "stats".

\section{Results}

\subsection{Honey bee survival}

The exposure of larvae to thiamethoxam at the concentration of $1.44 \mathrm{ng} / \mu \mathrm{L}$ affected the survival of individuals with higher mortality rates at day 8 (Cox model $P \leq 0.01$, Fig. 1 ). Pupae exposed to the concentrations of 0.001 and $1.44 \mathrm{ng} / \mu \mathrm{L}$ exhibited a significant decrease of the survival rate (Cox model $P \leq 0.05$, Fig. 2). However, there was no effect on survival in larvae exposed to 0.00001 and $0.001 \mathrm{ng} / \mu \mathrm{L}$ and in pupae exposed to $0.00001 \mathrm{ng} / \mu \mathrm{L}$ thiamethoxam (Figs. 1 and 2). Regarding the adult emergence rate, a significant decrease was observed with exposures at the concentration of 0.001 and $1.44 \mathrm{ng} / \mu \mathrm{L}$ thiamethoxam because of the increased mortality of larvae and pupae (Chi-Square test $P \leq 0.001$, Fig. 3). Furthermore, independent of the experimental group, an increase in mortality was observed during the periods of transition from larvae to pupae, which occurred at day 13 , and from pupae to adult, which occurred at day 20 (Fig. 4).

\subsection{Physiological effects of thiamethoxam}

The physiological effects of thiamethoxam on individuals of different ages (immature stages and adults) were assessed with physiological biomarkers. Thiamethoxam modulated the activity of AChE in larvae, pupae and emerging bees. Larvae exposed at $1.44 \mathrm{ng} / \mu \mathrm{L}$ showed an increase of AChE activity $(5.51 \pm 1.26$ and $7.56 \pm 0.40 \mathrm{mAU} / \mathrm{min} / \mathrm{mg}$ tissue in control and exposed bees, respectively) (Mann Whitney $U$ tests, $P \leq 0.05$, Fig. 5). For pupae and emerging bees, a significant increase of AChE activity was observed in all thiamethoxam-exposed groups (Mann-Whitney $U$ test, $P \leq 0.05$, Fig. 5). For pupae exposed to thiamethoxam at $0.00001,0.001$ and $1.44 \mathrm{ng} / \mu \mathrm{L}, \mathrm{AChE}$ activities were $61.06 \pm 11.54$, $55.80 \pm 10.82$ and $60.30 \pm 6.99 \mathrm{mAU} / \mathrm{min} / \mathrm{mg}$ tissue, respectively, and were higher than that of the control (of $40.99 \pm 6.93 \mathrm{mAU} / \mathrm{min} /$ $\mathrm{mg}$ tissue). For emerging bees exposed to thiamethoxam at $0.00001,0.001$ and $1.44 \mathrm{ng} / \mu \mathrm{L}, \mathrm{AChE}$ activities were $114.38 \pm 11.02$; $117.14 \pm 9.91$ and $117.47 \pm 8.77 \mathrm{mAU} / \mathrm{min} / \mathrm{mg}$ tissue and were higher than that of the control (93.2 $8 \pm 9.89 \mathrm{mAU} / \mathrm{min} / \mathrm{mg}$ tissue).

For the enzymes related to the metabolism of xenobiotics, the activities of GST and CaEp showed significant increases only in pupae (Mann-Whitney $U$ tests, $P<0.05$, Figs. 6 and 7). The activity of GST was $202.26 \pm 6.99 ; 197.16 \pm 3.16$ and $194.75 \pm 2.31 \mathrm{mAU} /$ $\mathrm{min} / \mathrm{mg}$ tissue in pupae exposed to thiamethoxam at 0.00001 , 0.001 and $1.44 \mathrm{ng} / \mu \mathrm{L}$, respectively, and $188.82 \pm 6.27 \mathrm{mAU} / \mathrm{min} / \mathrm{mg}$ tissue in the control (Fig. 6). For CaEp, the activities were $201.88 \pm 6.99 ; 196.78 \pm 3.16$ and $194.37 \pm 2.31 \mathrm{mUA} / \mathrm{min} / \mathrm{mg}$ tissue in pupae exposed to thiamethoxam at $0.00001,0.001$ and $1.44 \mathrm{ng} /$ $\mu \mathrm{L}$, respectively, and $188.45 \pm 6.27 \mathrm{mAU} / \mathrm{min} / \mathrm{mg}$ tissue in the control (Fig. 7). No effect of thiamethoxam was observed in larvae and emerging bees (Fig. 8). In the pupal stages, ALP activity was not detected.

\section{Discussion}

Few studies have evaluated the effects of insecticides, and particularly thiamethoxam, on the developmental phase of honey bees, although the success of this phase is dependent on large changes in tissues, such as the modelling of the brain (Chapman, 
Version définitive du manuscrit publiée dans / Final version of the manuscript published in :

Environmental Pollution (2017), Vol. 229, p. 386-393, DOI: 10.1016/j.envpol.2017.05.092

Journal homepage: www.elsevier.com/locate/envpol

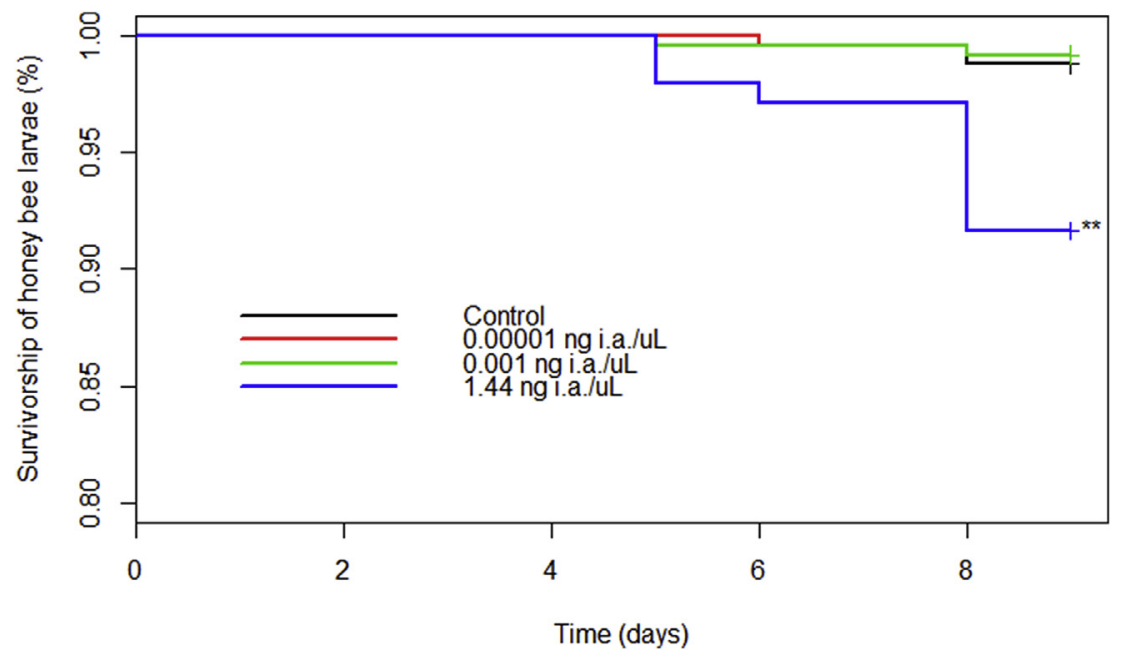

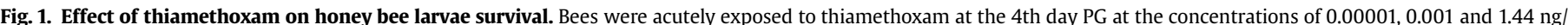

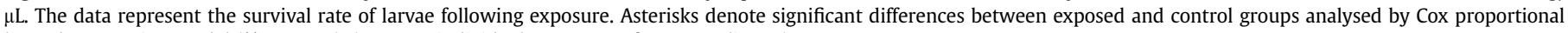
hazards regression model $\left({ }^{* *} p \leq 0.01\right)$. ( $n=336$ individuals per group from 7 replicates $)$.

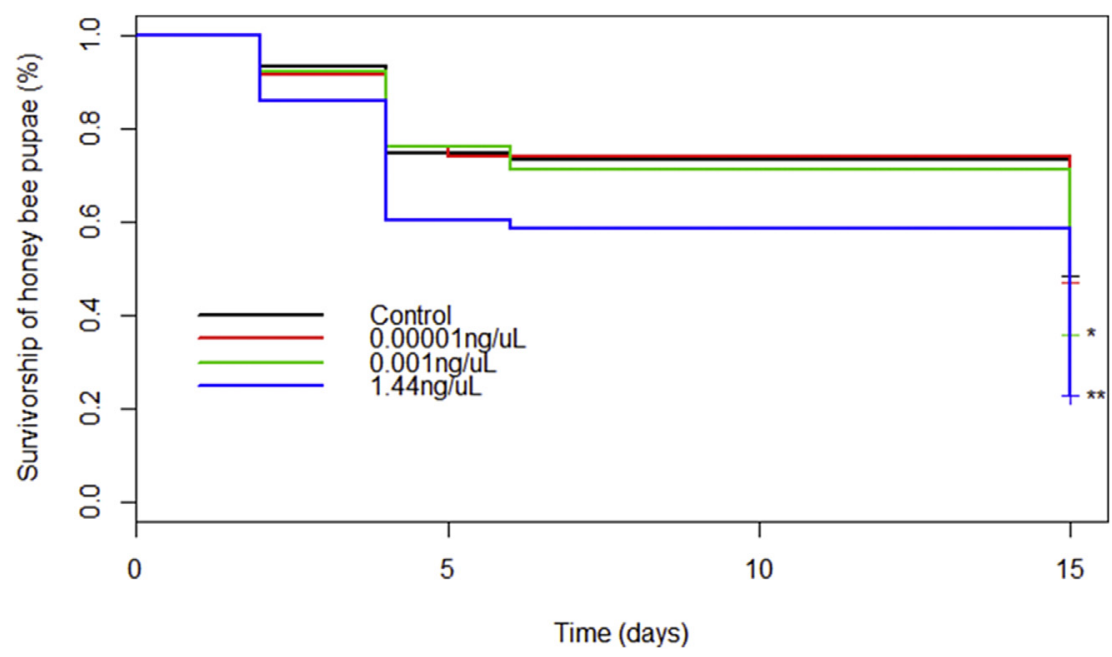

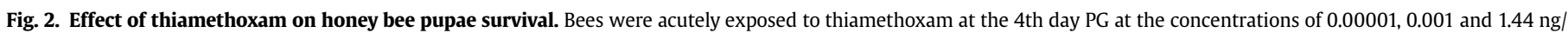

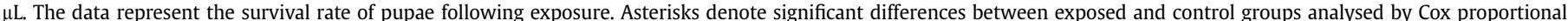
hazards regression model $\left({ }^{*} p \leq 0.05\right.$ and $\left.{ }^{* *} p \leq 0.01\right)(n=240$ individuals per group from 5 replicates).

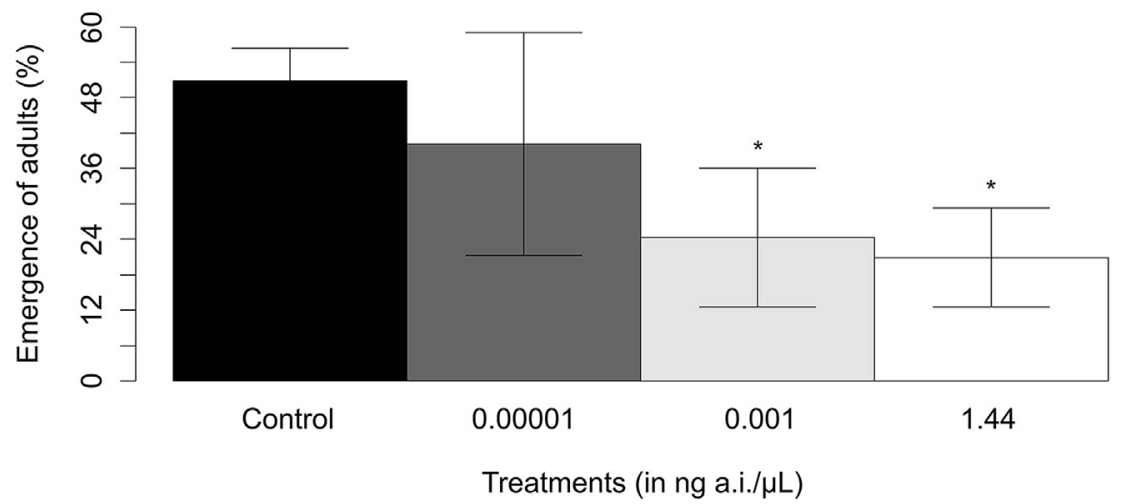

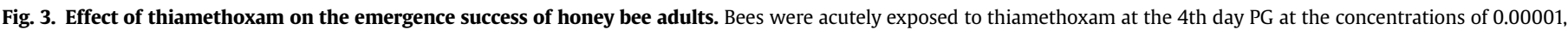

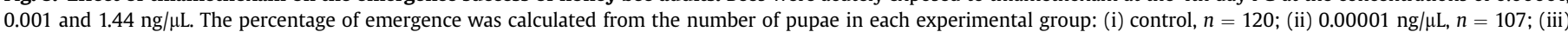

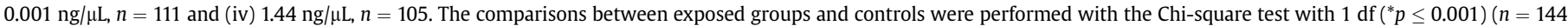

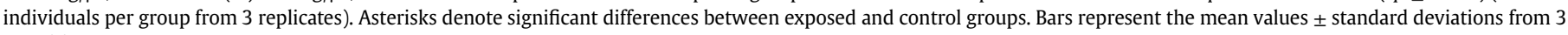
repetitions. 
Version définitive du manuscrit publiée dans / Final version of the manuscript published in :

Environmental Pollution (2017), Vol. 229, p. 386-393, DOI: 10.1016/j.envpol.2017.05.092

Journal homepage: www.elsevier.com/locatelenvpol

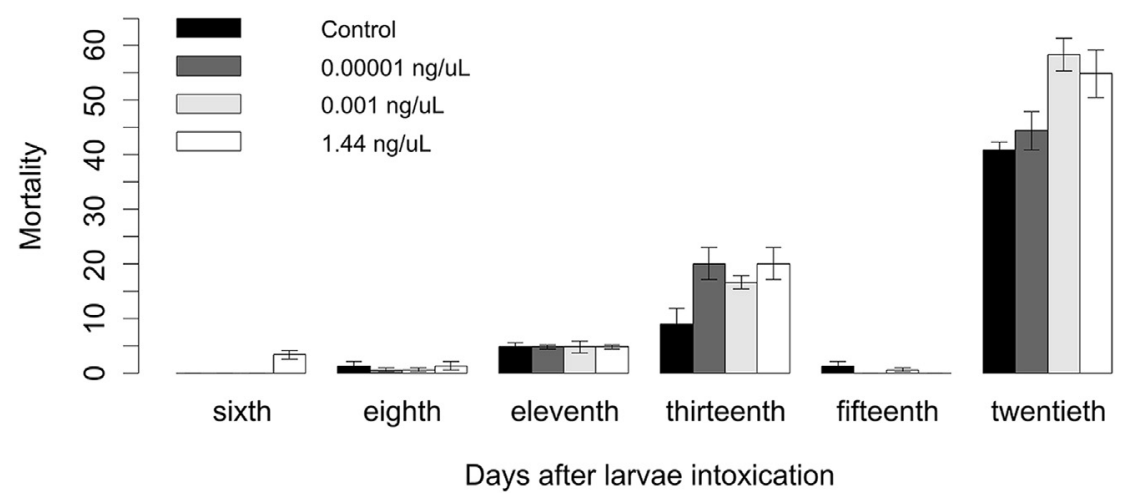

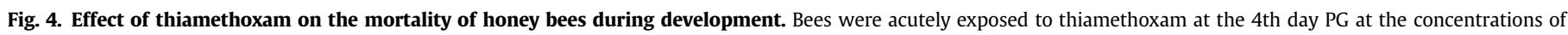
$0.00001,0.001$ and $1.44 \mathrm{ng} / \mu \mathrm{L}(n=144$ individuals per group from 3 replicates). Bars represent the mean mortality values \pm standard deviations from 3 repetitions.
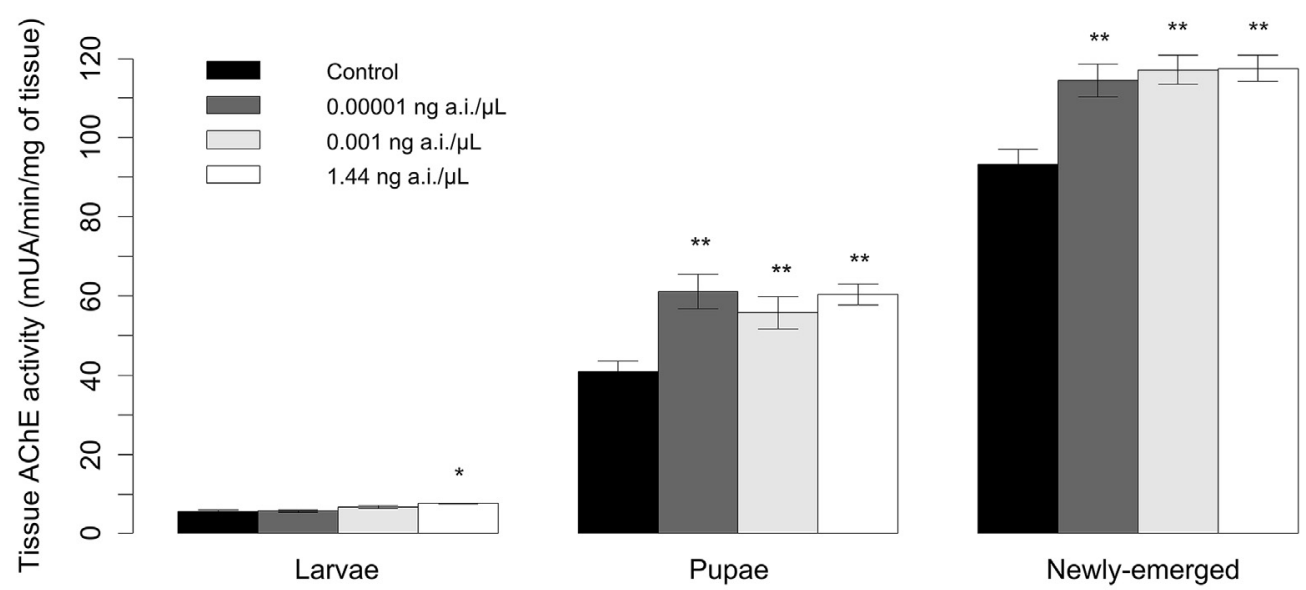

Phases of honey bee development

Fig. 5. Effects of thiamethoxam on acetylcholinesterase. Bees were acutely exposed to thiamethoxam at the 4 th day PG at the concentrations of $0.00001,0.001$ and $1.44 \mathrm{ng} / \mu \mathrm{L}$. Acetylcholinesterase (AChE) activity was measured in 5th instar larvae (A), the head of pupae (Pdl) (B) and the head of emerging bees (C). Bars represent the mean values \pm SD of 7 repetitions performed in triplicate. Asterisks denote significant differences between exposed groups and their respective control groups analysed by Mann-Whitney $U$ tests $\left({ }^{*} p \leq 0.05,{ }^{* *} p \leq 0.005\right)$
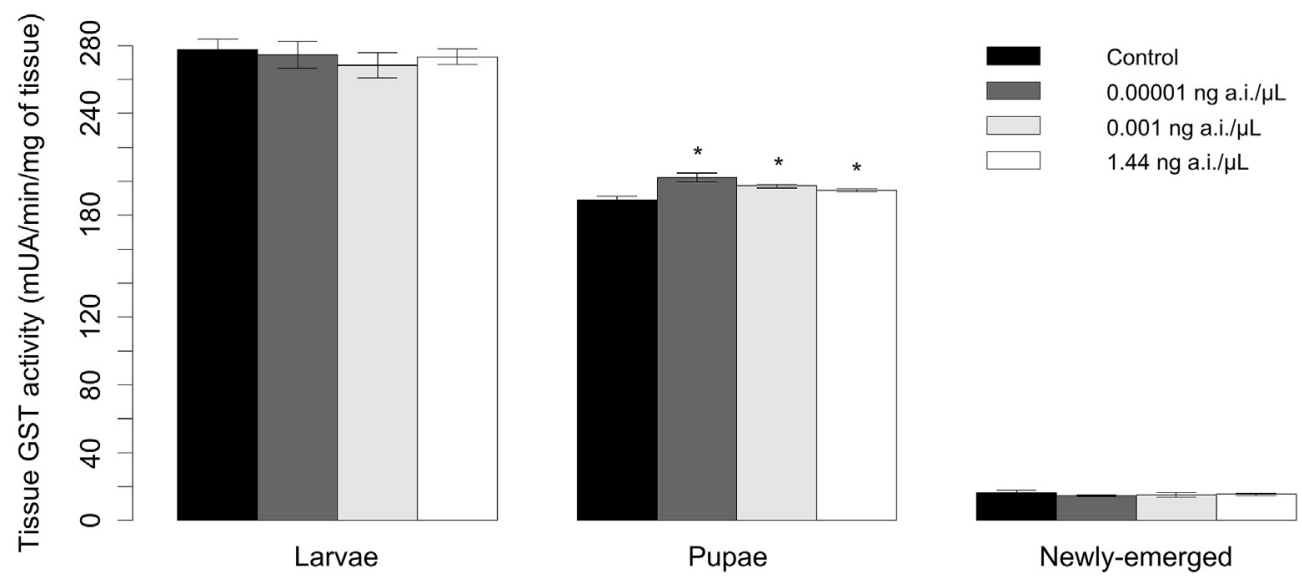

Phases of honey bee development

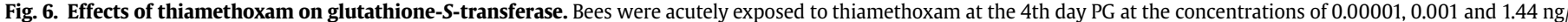

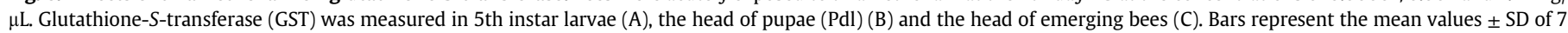
repetitions. Asterisks denote significant differences between exposed groups and their respective control groups analysed by Mann-Whitney $U$ tests $\left({ }^{*} p \leq 0.05\right.$, $\left.{ }^{* *} p \leq 0.005\right)$. 


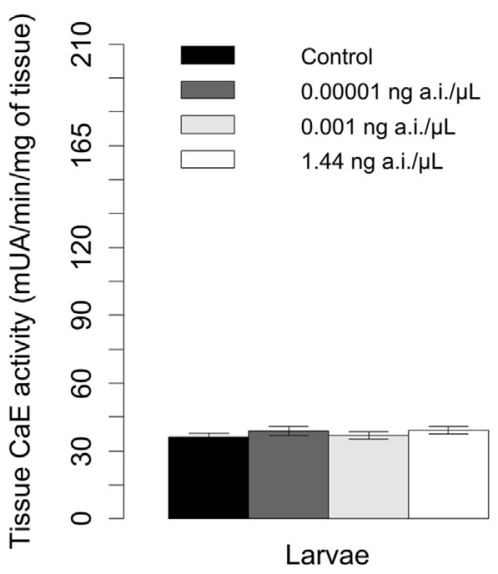

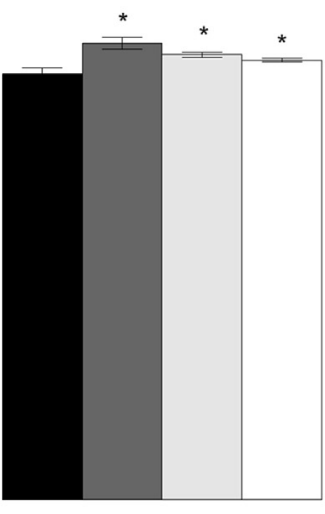

Pupae

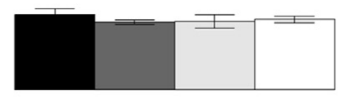

Newly-emerged

Phases of honey bee development

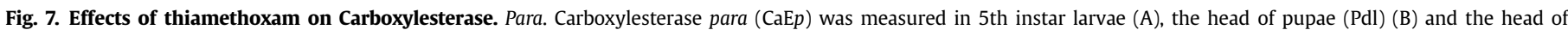

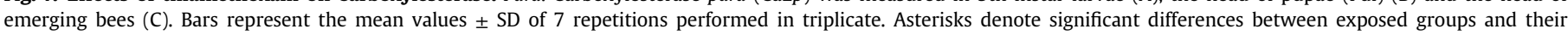
respective control groups analysed by Mann-Whitney $U$ tests $\left({ }^{*} p \leq 0.05,{ }^{* *} p \leq 0.005\right)$.
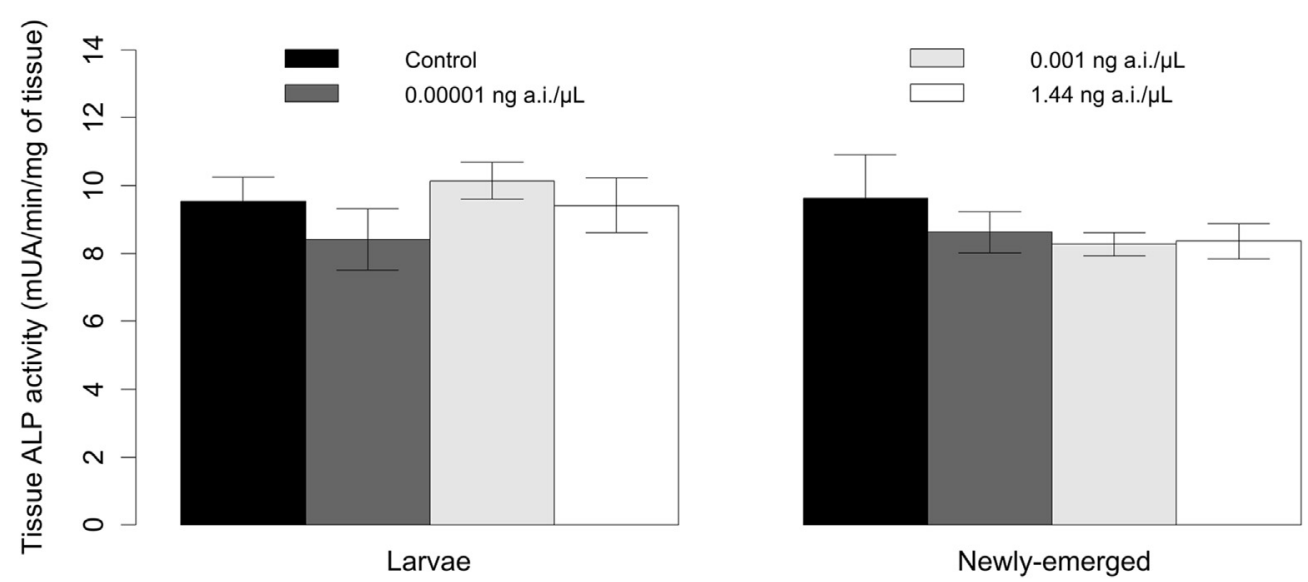

Phases of honey bee development

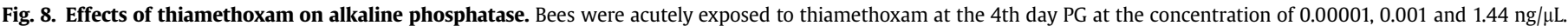

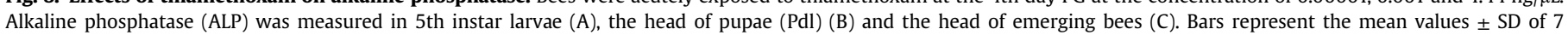
repetitions performed in triplicate. Mann-Whitney $U$ tests $\left({ }^{*} p \leq 0.05,{ }^{* *} p \leq 0.005\right)$.

1998; Roat and Landim, 2010), and is crucial for the fitness of adults (Desneux et al., 2007; Yang et al., 2012; Cousin et al., 2013). This study represents the first investigation on the effects of thiamethoxam on the development of $A$. mellifera after exposure at larval stages. Our results demonstrate that acute exposures of $A$. mellifera larvae to thiamethoxam reduce the survival of larvae, pupae and the emergence rate of adult honey bees. They also disrupt the physiology by modifying the activity of AChE, at all developmental stages, and GST and CaEp at pupal stages.

Regarding larval survival, only the highest thiamethoxam concentration had a lethal effect on larvae. However, it is very important to consider that delayed effects may occur during development or at the adult stage. This can be exemplified by the concentration of $0.001 \mathrm{ng} / \mu \mathrm{L}$ that did not change the survival rate of larvae but decreased the survival of pupae and thus the percentage of emerging bees. Grillone et al. (2017) in evaluating the effects of thiamethoxam on the development of $A$. mellifera found different sublethal late effects including like brownish larvae, duplication of the pupal integument, delay in development, and deformed adults.

In addition to survival, it should be considered that late effects on development can occur and that the functional integrity of adults may be impaired. Thus, exposure to neonicotinoids at doses that did not induce mortality in larvae can impair learning performance in adults (Yang et al., 2012) or can induce the appearance of atypical neurons in the brains of larvae (Tavares et al., 2015).

The effects on survival were observed only from the 8th day. Thus, it is possible to assume that both thiamethoxam and its metabolites are involved in the toxicity. This assumption is in accordance with the results showing that neonicotinoids may accumulate in bee tissues and that metabolites are involved in the toxicity through a metabolic relay (Suchail et al., 2001, 2004; Yang et al., 2012; Zhu et al., 2014). In addition, as honey bee larvae do no defecate until the pupal stage, metabolites may accumulate and thus increase the toxicity of the parent substance (Michelette and Soares, 1993; Cruz-Landim, 2009; Suchail et al., 2001, 2004).

In this study, it was observed that mortality presented peaks that coincided with the periods of transition in the development, larva to pupa (13-d) and pupa to adult (20-d) both in control and exposed individuals. This outcome not only highlights the importance of these periods in the success of honey bee development 
(Cruz-Landim, 2009) but also reveals that these periods should be considered at risk for exposures to pesticides. Thus, effects on the survival of pupae and adult emergence might originate from a particular susceptibility during metamorphosis.

After exposure to thiamethoxam, pupae and emerging bees exhibit a significant increase in AChE activity in all exposed groups. $\mathrm{AChE}$ is an enzyme that hydrolyses the neurotransmitter acetylcholine $(\mathrm{ACh})$ in cholinergic synapses for the rapid and precise control of nerve transmission (Massoulié et al., 1993; Badiou et al., 2008). Thus, the increase of AChE might be a biological response to compensate the permanent activation of cholinergic neurons due to the strong binding of thiamethoxam to nicotinic acetylcholine receptors (nAChR). However, whatever the mechanisms by which $\mathrm{AChE}$ is increased, these results exemplify the interest in AChE as a pertinent biomarker of exposure to neonicotinoids (Boily et al., 2013; Badiou-Beneteau et al., 2013).

CaEp and GST are phase I and phase II enzymes involved in the detoxification of xenobiotics (Claudianos et al., 2006; Badawy et al., 2015; Berenbaum and Johnson, 2015; Dussaubat et al., 2016). CaEp and GST showed an increase in activity during the pupal stage and in the individuals of all exposed groups. Their activity could have increased as a biological response to detoxify thiamethoxam. However, GST is also involved in the detoxification of reactive oxygen species, and its increase could be the consequence of the induction of oxidative stress by thiamethoxam (Kostaropoulos et al., 2001; Barata et al., 2005; Babczynska et al., 2006). In addition, under normal conditions the amount of GST is higher in pupae than in larvae and adults, as reported by Diao et al. (2006) and according to our results. Since there is a high amount of this enzyme in the pupae phase, its increase following exposure to thiamethoxam should be a rapid physiological protective response. Nielsen et al. (2000) evaluated the effect of flumethrin on Apis mellifera lingustica Spinola, and also observed an increase of GST in larvae, pupae and nurse bees, which is more notable in larvae and pupae. This demonstrates the importance of GST in detoxification during the pupal phase and suggests that its activity may be very important in the metabolization of insecticides during this phase.

Concerning carboxylesterases, these enzymes appear very sensitive to the exposure to pesticides and can be easily modulated by neonicotinoids, as shown for $\mathrm{CaE} \alpha, \mathrm{CaE} \beta$ and $\mathrm{CaEp}$ (BadiouBeneteau et al., 2012; Dussaubat et al., 2016). They are enzymes that besides being involved in detoxification, also act in the degradation of the juvenile hormone during the development of A. mellifera. Since juvenile hormone is associated with development, we can relate the high amount of carboxylesterases in the pupal phase with the decrease of the juvenile hormone that occurs at this stage (Truman and Riddiford, 1999). For larvae and newlyemerged honey bees, there were no differences in the enzymatic activity of GST and CaEp. It is important to consider that each stage of life must rely on its specific defence mechanisms. For example, larvae have a large amount of fat body that probably plays an important role in detoxification because this tissue is rich in cytochromes P450. For adults honey bees, the susceptibility of A. mellifera to xenobiotics may also be related to the fact that there is a low amount of GST and other detoxification enzymes (Claudianos et al., 2006).

The basic structure of the intestine of larvae and pupae is similar but, during metamorphosis, the intestine is extensively reorganized to fit the body of the adult bees (Cruz-Landim, 2009; Moss, 1992). However, ALP activity was not detected during the pupal stage. This could be due to the fact that this enzyme is involved in the hydrolysis of phosphate groups and in the absorption of substances not present in the food of pupae.

We demonstrated that the exposure of $A$. mellifera larvae to thiamethoxam, at concentrations similar to or lower than those found in field, may affect the survival rate, the emergence success and the physiology of bees at the larval, post-embryonic and adult stages. It is legitimate to think that these effects may jeopardize the survival of $A$. mellifera colonies, alone or in combination with effects induced by other chemical or biological stressors. These results are important for the process of pesticide registration because they emphasize the necessity of assessing the toxicity of plant protection products on developmental stages.

\section{Acknowledgements}

The authors would like to thank the São Paulo Research Foundation for providing the scholarship BEPE (grants 2013/21634-8) and the thematic project (grants 2012/50197-2). We thank also G. Kairo and M. Cousin for their technical help.

\section{References}

Aupinel, P.F., Dufuor, D.H., Tasei, J.N., Michaud, B., Odoux, J.F., Pham-Delègue, M.H. 2005. Improvement of artificial feeding in a standart in vitro method for rearing Apis mellifera larvae. Bull. Insectology 58, 107-111.

Aupinel, P., Fortini, D., Michaud, B., Marolleau, F., Tasei, J.N., Odoux, J.F., 2007. Toxicity of dimethoate and fenoxycarb to honey bee brood (Apis mellifera), using a new in vitro standardized feeding method. Pest Manag. Sci. 63, 1090-1094.

Babczynska, A., Wilczek, G., Migula, P., 2006. Effects of dimethoate on spiders from metal pollution gradient. Sci. Total Environ. 370, 352-359.

Badawy, M.E.I., Nasr, H.M., Rabea, E.I., 2015. Toxicity and biochemical changes in the honey bee Apis mellifera exposed to four insecticides under laboratory conditions. Apidologie 46, 177-193.

Badiou, A., Meled, M., Belzunces, L.P., 2008. Honeybee Apis mellifer acetylcholinesterase-a biomarker to detect deltamethrin exposure. Ecotoxicol. Environ. Saf. 69, 246-253.

Badiou-Beneteau, A., Carvalho, S.M., Brunet, J.L., et al., 2012. Development of biomarkers of exposure to xenobiotics in the honey bee Apis mellifera: application to the systemic insecticide thiamethoxam. Ecotoxicol. Environ. Saf. 82, 22-31.

Badiou-Beneteau, A., Benneveau, A., Geret, F., et al., 2013. Honeybee biomarkers as promising tools to monitor environmental quality. Environ. Int. 60, 31-41.

Barata, C., Lekumberri, I., Vila-Escale, M., Prat, N., Porte, C., 2005. Trace metal concentration, antioxidant enzyme activities and susceptibility to oxidative stress in the tricoptera larvae Hydropsyche exocellata from the Llobregat river basin (NE Spain). Aquat. Toxicol. 74, 3-19.

Becher, M.A., Osborne, J.L., Thorbek, P., Kennedy, P.J., Grimm, V., 2013. Towards a systems approach for understanding honeybee decline: a stocktaking and synthesis of existing models. J. Appl. Ecol. 50, 868-880.

Beekman, M., Ratnieks, F.L.W., 2000. Long-range foraging by the honey-bee, Apis mellifera L. Funct. Ecol. 14, 490-496.

Berenbaum, M.R., Johnson, R., 2015. Xenobiotic detoxification pathways in honeybees. Curr. Opin. Insect Sci. 10, 51-58.

Blacquiere, T., Smagghe, G., van Gestel, C.A., Mommaerts, V., 2012. Neonicotinoids in bees: a review on concentrations, side-effects and risk assessment. Ecotoxicology 21, 973-992.

Boily, M., Sarrasin, B., DeBlois, C., Aras, P., Chagnon, 2013. Acetylcholinesterase in honey bees (Apis mellifera) exposed to neonicotinoids, atrazine and glyphosate: laboratory and field experiments. Environ. Sci. Pollut. Res. Int. 20, 5603-5614.

Bonmatin, J.-M., Giorio, C., Girolami, V., Goulson, D., Kreutzweiser, D.P., Krupke, C., Liess, M., Marzaro, M., Mitchell, E.A.D., Noome, D.A., Simon-Delso, N., Tapparo, A., 2014. Environmental fate and exposure; neonicotinoids and fipronil. Environ. Sci. Pollut. Res. Int. 22, 35-67.

Breeze, T.D., Bailey, A.P., Balcombe, K.G., Potts, S.G., 2011. Pollination services in the UK: how important are honeybees? Agr. Ecosyst. Environ. 142, 137-143.

Carvalho, S.M., Belzunces, L.P., Carvalho, G.A., Brunet, J.L., Badiou-Beneteau, A., 2013. Enzymatic biomarkers as tools to assess environmental quality: a case study of exposure of the honeybee Apis mellifera to insecticides. Environ. Toxicol. Chem. 32, 2117-2124.

Chapman, R.F., 1998. The insects: structure and function. Cambridge University Press, Cambridge.

Chauzat, M.-P., Cauquil, L., Roy, L., Franco, S., Hendrikx, P., Ribière-Chabert, M., 2013. Demographics of the european apicultural industry. PLoS One 8 (11), e79018.

Claudianos, C., Ranson, H., Johnson, R.M., Biswas, S., Schuler, M.A., Berenbaum, M.R., Feyereisen, R., Oakeshott, J.G., 2006. A deficit of detoxification enzymes: pesticide sensitivity and environmental response in the honeybee. Insect Mol. Biol. 15, 615-636.

Cousin, M., Silva-Zacarin, E., Kretzschmar, A., El Maataoui, M., Brunet, J.L. Belzunces, L.P., 2013. Size changes in honey bee larvae oenocytes induced by exposure to Paraquat at very low concentrations. PloS One 8 (5), e65693.

Couvillon, M.J., Schürch, R., Ratnieks, F.L.W., 2014. Waggle dance distances as integrative indicators of seasonal foraging challenges. PloS One 9 (4), e93495. Cruz-Landim, C., 2009. Morfologia e função de sistemas. Editora Unesp, São Paulo. 
Desneux, N., Decourtye, A., Delpuech, J.M., 2007. The sublethal effects of pesticides on beneficial arthropods. Annu. Rev. Entomol. 52, 81-106.

Diao, Q., Yuan, K., Liang, P., Gao, X., 2006. Tissue distribution and properties of glutathione-S-transferases in Apis cerana cerana Fabricius and Apis mellifera ligustica Spinola. J. Apic. Res. 45, 145-152.

Dussaubat, C., Maisonnasse, A., Crauser, D., Tchamitchian, S., Bonnet, M., Cousin, M. Kretzschmar, A., Brunet, J.-L., Le Conte, Y., 2016. Combined neonicotinoid pesticide and parasite stress alter honeybee queens'physiology and survival. Sci. Rep. 6, 31430.

Elston, C., Thompson, H.M., Walters, K.F.A., 2013. Sub-lethal effects of thiamethoxam, a neonicotinoid pesticide, and propiconazole, a DMI fungicide, on colony initiation in bumblebee (Bombus terrestris) micro-colonies. Apidologie 44, 563-574.

Gallai, N., Salles, J.-M., Settele, J., Vaissière, B.E., 2009. Economic valuation of the vulnerability of world agriculture confronted with pollinator decline. Ecol. Econ. 68, 810-821.

Gill, R.J., Ramos-Rodriguez, O., Raine, N.E., 2012. Combined pesticide exposure severely affects individual- and colony-level traits in bees. Nature 491, 105-108.

Giroud, B., Vauchez, A., Vulliet, E., Wiest, L., Buleté, A., 2013. Trace level determination of pyrethroid and neonicotinoid insecticides in beebread using acetonitrile-based extraction followed by analysis with ultra-high-performance liquid chromatography-tandem mass spectrometry. J. Chromatogr. A 1316 $53-61$.

Goulson, D., Nicholls, E., Botías, C., Rotheray, E.L., 2015. Bee declines driven by combined stress from parasites, pesticides, and lack of flowers. Science 347 (6229), 1255957.

Grillone, G., Laurino, D., Manino, A., Porporato, M., 2017. Toxicity of thiamethoxam on in vitro reared honey bee brood. Apidologie. http://dx.doi.org/10.1007/ s13592-017-0506-6.

Henry, M., Beguin, M., Requier, F., et al., 2012. A common pesticide decreases foraging success and survival in honey bees. Science 336 (6079), 348-350.

Johnson, R.M., 2015. Honey bee toxicology. Annu. Rev. Entomol. 60, 415-434.

Jovanovic-Galovic, A., Blagojevic, D.P., Grubor-Lajsic, G., Worland, R., Spasic, M.B., 2004. Role of antioxidant defense during different stages of preadult life cycle in European corn borer (Ostrinia nubilalis, Hubn.): diapause and metamorphosis. Arch. Insect Biochem. Physiol. 55, 79-89.

Klein, A.M., Vaissiere, B.E., Cane, J.H., et al., 2007. Importance of pollinators in changing landscapes for world crops. Proc. R. Soci 274, 303-313.

Kessler, S.C., Tiedeken, E.J., Simcock, K.L., Derveau, S., Mitchell, J., Softley, S. Stout, J.A., Wright, G., 2015. Bees prefer foods containing neonicotinoid pesticides. Nature 521, 74-76.

Kostaropoulos, I., Papadopoulos, A.I., Metaxakis, A., Boukouvala, E., PapadopoulouMourkidou, E., 2001. Glutathione-S-transferase in the defence against pyrethroids in insects. Insect Biochem. Mol. Biol. 31, 313-319.

Krupke, C.H., Hunt, G.J., Eitzer, B.D., Andino, G., Given, K., 2012. Multiple routes of pesticide exposure for honey bees living near agricultural fields. PloS one 7 (1) e29268.

Lallès, J.P. 2010. Intestinal alkaline phosphatase: multiple biological roles in maintenance of intestinal homeostasis and modulation by diet. Nutr. Rev. 68, $323-332$.

Laycock, I., Cotterell, K.C., O'Shea-Wheller, T.A., Cresswell, J.E., 2014. Effects of the neonicotinoid pesticide thiamethoxam at field-realistic levels on microcolonies of Bombus terrestris worker bumble bees. Ecotoxicol. Environ. Saf. 100, 153-158.

Maienfisch, P., Huerlimann, H., Rindlisbacher, A., et al., 2001. The discovery of thiamethoxam: a second-generation neonicotinoid. Pest Manag Sci. 57, 165-176.

Massoulié, J., Pezzementi, L., Bon, S., Krejci, E., Vallette, F.M., 1993. Molecular and cellular biology of cholinesterases. Prog. Neurobiol. 41, 31-91.

Maxwell, D.M., 1992. The specificity of carboxylesterase protection against the toxicity of organophosphorus compounds. Toxicol. Appl. Pharmacol. 114 306-312.

Michelette, E.R.F. Soares, A.E.E., 1993. Characterization of preimaginal developmental stages in Africanized honey bee workers (Apis mellifera L). Apidologie 24, 431-440.

Millán, J.L., 2006. Alkaline phosphatase. Structure, substrate specificity and functional relatedness to other members of a large superfamily of enzymes. Purigenic Signal 2, 335-341.

Mommaerts, V., Reynders, S., Boulet, J., Besard, L., Sterk, G., Smagghe, G., 2010. Risk assessment for side-effects of neonicotinoids against bumblebees with and without impairing foraging behavior. Ecotoxicology 19, 207-215.

Moss, D.W., 1992. Perspectives in alkaline phosphatase research. Clin. Chem. 38
2486-2492.

Mullin, C.A., Frazier, M., Frazier, J.L., et al., 2010. High levels of miticides and agrochemicals in North American apiaries: implications for honey bee health. PloS One 5 (3), e9754.

Nielsen, S.A., Brodsgaard, C.J., Hansen, H., 2000. Effects on detoxification enzymes in different life stages of honey bees (Apis mellifera L., Hymenoptera:Apidae) treated with a synthetic pyrethroid (flumethrin). Altern. Lab. Anim. 28, 437-443.

OECD Guidelines for the testing of chemicals, 2013. Honey bee (Apis mellifera) larval toxicity test, single exposure no 237.

Pilling, E., Campbell, P., Coulson, M., Ruddle, N., Tornier, I., 2013. A four-year field program investigating long-term effects of repeated exposure of honey bee colonies to flowering crops treated with thiamethoxam. PloS One 8 (10), e77193.

Potts, S.G., Biesmeijer, J.C., Kremen, C., Neumann, P., Schweiger, O., Kunin, W.E., 2010. Global pollinator declines: trends, impacts and drivers. Trends Ecol. Evol. $25,345-353$.

Ratnieks, F.L.W., Carreck, N.L., 2010. Clarity on honey bee collapse? Science 327 (5962), 152-153.

R Development Core Team, 2015. R: a language and environment for statistical computing. R Foundation for Statistical Computing, Vienna, ISBN 3-900051-070. http://www.R-project.org/.

Rembold, H., Kremer, J.-P., Ulrich, G.M., 1980. Characterization of postembryonic developmental stages of the female castes of the honey bee, Apis mellifera $\mathrm{L}$. Apidologie 11, 29-38.

Roat, T.C., Landim, C.D.C., 2010. Mitosis and cell death in the optic lobes of workers, queens and drones of the honey bee (Apis mellifera) during metamorphosis. J. Biosci. 35, 415-425.

Rortais, A.S., Arnold, G.R., Halm, M.-P., Touffet-Briens, F.D.R., 2005. Modes of honeybees exposure to systemic insecticides: estimated amounts of contaminated pollen and nectar consumed by different categories of bees. Apidologie 36, $71-83$.

Sanchez-Bayo, F., Goka, K., 2014. Pesticide residues and bees:a risk assessment. PloS One 9 (4) e94482.

Sparks, T.C., Nauen, R., 2014. IRAC: mode of action classification and insecticide resistance management. Pestic. Biochem. Phys. 121, 122-128.

Stokstad, E., 2007. The case of the empty hives. Science 316 (5827), 970-972.

Stoner, K.A., Eitzer, B.D., 2012. Movement of soil-applied imidacloprid and thiamethoxam into nectar and pollen of squash (Cucurbita pepo). PloS One 7 (6), e39114.

Suchail, S, Guez, D. Belzunces, L.P. 2001. Discrepancy between acute and chronic toxicity induced by imidacloprid and its metabolites in Apis mellifera. Environ. Toxicol. Chem. 2001 (20), 2482-2486.

Suchail, S., Sousa, G., Rahmani, R., Belzunces, L.P., 2004. In vivo distribution and metabolisation of ${ }^{14} \mathrm{C}$-imidacloprid in different compartments of Apis mellifera L. Pest Manag. Sci. 60, 1056-1062.

Tavares, D.A., Roat, T.C., Carvalho, S.M., Silva-Zacarin, E.C.M., Malaspina, O., 2015 In vitro effects of thiamethoxam on larvae of Africanized honey bee Apis mellifera (Hymenoptera: apidae). Chemosphere 135, 370-378.

Tomizawa, M., Casida, J.E., 2003. Selective toxicity of neonicotinoidsattributable to specificity of insect and mammalian nicotinic receptors. Annu. Rev. Entomol. 48, 339-364.

Truman, J.W., Riddiford, L.M., 1999. The origins of insect metamorphosis. Nature 401, 447-452.

Whitehorn, P.R., O'Connor S., Wackers, FI Goulson, D. 2012 Neonicotinoid pesticide reduces bumble bee colony growth and queen production. Science 336 (6079), 351-352.

Wiest, L., Buleté, A., Giroud, B., Fratta, C., Amic, S., Lambertb, O., Pouliquenb, H. Arnaudguilhema, C., 2011. Multi-residue analysis of 80 environmental contaminants in honeys, honeybees and pollens by one extraction procedure followed by liquid and gas chromatography coupled with mass spectrometric detection. J. Chomattogr. 1218, 5743-5756.

Yang, E.C., Chang, H.C., Wu, W.Y., Chen, Y.W., 2012. Impaired olfactory associative behavior of honeybee workers due to contamination of imidacloprid in the larval stage. PloS one 7 (11), e49472.

Yu, S.J., Robinson, F.A., Nation, J.L., 1984. Detoxication capacity in the honey bee, Apis mellifera L. Pestic. Biochem. Phys. 22, 360-368.

Zhu, W., Schmehl, D.R., Mullin, C.A., Frazier, J.L., 2014. Four common pesticides, their mixtures and a formulation solvent in the hive environment have high oral toxicity to honey bee larvae. PloS one 9 (1), e77547. 